Florida International University FIU Digital Commons

$11-9-2010$

\title{
The Economic-Dynamics of the Military in Communist Regimes: A Comparison of Cuba, China and Vietnam
}

Michael J. Aranda

Florida International University, mike_aranda@hotmail.com

DOI: $10.25148 /$ etd.FI10120602

Follow this and additional works at: https://digitalcommons.fiu.edu/etd

Part of the International and Area Studies Commons

\section{Recommended Citation}

Aranda, Michael J., "The Economic-Dynamics of the Military in Communist Regimes: A Comparison of Cuba, China and Vietnam" (2010). FIU Electronic Theses and Dissertations. 296.

https://digitalcommons.fiu.edu/etd/296 


\section{FLORIDA INTERNATIONAL UNIVERSITY}

Miami, Florida

THE ECONOMIC-DYNAMICS OF THE MILITARY IN COMMUNIST REGIMES: A COMPARISON OF CUBA, CHINA AND VIETNAM

A thesis submitted in partial fulfillment of the

requirements for the degree of

MASTER OF ARTS

in

INTERNATIONAL STUDIES

by

Michael J. Aranda

2010 
To: Dean Kenneth Furton

College of Arts and Sciences

This thesis, written by Michael J. Aranda, and entitled The Economic-Dynamics of the Military in Communist Regimes: A Comparison of Cuba, China and Vietnam, having been approved in respect to style and intellectual content, is referred to you for judgment.

We have read this thesis and recommend that it be approved.

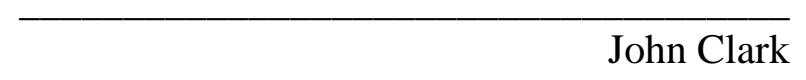

Astrid Arrarás

Félix Martín, Major Professor

Date of Defense: November 9, 2010

The thesis of Michael J. Aranda is approved.

Dean Kenneth Furton

College of Arts and Sciences

Interim Dean Kevin O’Shea

University Graduate School

Florida International University, 2010 
(C) Copyright 2010 by Michael J. Aranda

All rights reserved. 


\section{ACKNOWLEDGMENTS}

I wish to acknowledge and thank my committee members for all their help, support and patience in completing this thesis study. I would also like to thank my coworkers for their understanding every time I had to leave work in the middle of the day to dedicate time on this thesis. Lastly, I thank my friends and loved ones, especially my girlfriend Laura, my mother Carmen and my sister Liza. I am sure they have learned so much on communist militaries that they could probably write their own journal article on the subject. 


\author{
ABSTRACT OF THE THESIS \\ THE ECONOMIC-DYNAMICS OF THE MILITARY IN COMMUNIST REGIMES: A \\ COMPARISON OF CUBA, CHINA AND VIETNAM \\ by
}

Michael J. Aranda

Florida International University, 2010

Miami, Florida

Professor Félix Martín, Major Professor

The present study focuses on the factors that can increase or decrease militaryeconomic involvement in communist regimes. This anomalous form of military behavior, labeled as the Military Business Complex (MBC), emerged in various communist regimes in the 1980s. However, in the early 2000s, the communist governments of China and Vietnam began to decrease the number of industries managed by their military institutions, while these industries increased in Cuba. This current study asks why the Cuban MBC regime increased in the early 2000s, while the Chinese and Vietnamese ceased or reduced their MBC involvement. Through a comparative analysis of all three military institutions, this study argues that certain evolving elements within the communist-party-military spectrum in Cuba caused it to expand its military managedeconomy. By highlighting the different patterns of MBC evolution in communist regimes, this study sheds light on the general phenomenon of how military institutions exert political and economic influence. 


\section{TABLE OF CONTENTS}

SECTIONS

PAGE

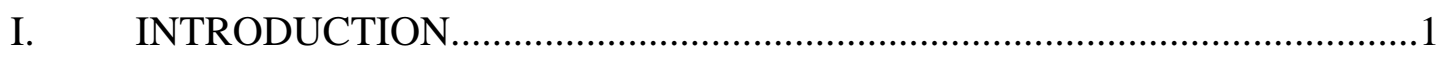

II. BACKGROUND AND LITERATURE ANALYSIS .................................10

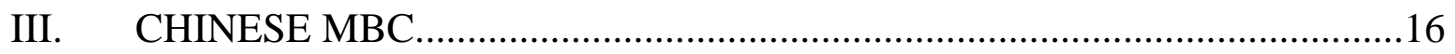

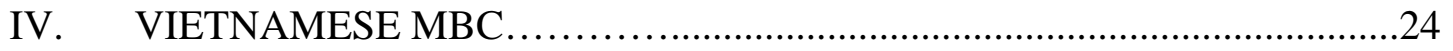

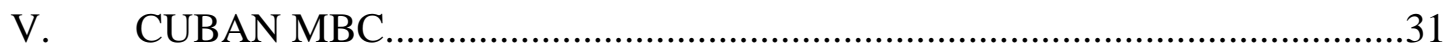

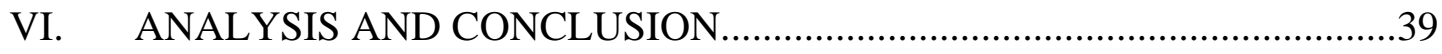

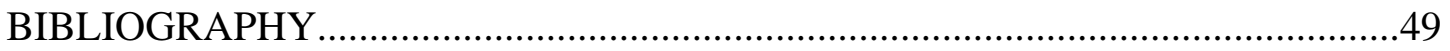




\section{LIST OF ABBREVIATIONS}

CCP: Chinese Communist Party

CMC: Central Military Commission

CMPC: Central Military Party Commission

DSE: Department of State Security

FAR: Fuerzas Armadas Revolucionarias, or Revolutionary Armed Forces

GLD: General Logistics Department

GOE: Group of Special Operations

GPD: General Political Directorate

ICP: Indochinese Communist Party

MININT: Ministry of Interior

MINFAR: Ministry of the Armed Forces

PLA: People’s Liberation Army

PCC: Partido Comunista de Cuba, or Cuban Communist Party

RMB: Renminbi

SRV: Socialist Republic of Vietnam

VCP: Vietnamese Communist Party

VPA: Vietnamese People’s Army

VWP: Vietnamese Workers’ Party 


\section{Section I: Introduction}

The Military Business Complex model (MBC) places the military apparatus in charge of economic and business dealings on behalf of the civilian communist authority. The Chinese People's Liberation Army (PLA) was engaged in an MBC regime between 1978 and 1998. Its economic holdings, which consisted of 20,000 enterprises in 1983, were severely reduced by the Chinese Communist Party (CCP) to less than 1,000 industries (Mulvenon 2001). The Vietnamese MBC regime, which was established in 1986 by the Vietnamese Communist Party (VCP), consisted of more than 300 enterprises in the 1990s and was managed by the Vietnamese People's Army (VPA). It was then reduced to less than 200 economic units by the early 2000s, and has been kept at that number. The Cuban MBC regime, however, is still in place in the economy and has grown in operation and management of the national economy since the early 2000s. For example, the Cuban Revolutionary Armed Forces, known as the FAR, managed between 100-250 economic units and industries in the early 1990s. This number increased to 1,400 economic businesses by 2006 (Klepak 2005).

This study analyzes the FAR, the PLA and the VPA institutions in their respective national economic roles. It is predominantly a comparative study using all three case studies, with a conclusion regarding each MBC regime. In addition, this study postulates a number of testable hypotheses that may help advance the research of other forms of military praetorian regimes.

Section one presents three independent variables and hypotheses which are discussed as possible explanations in relation to the research question that guides this work. Section two presents the background literature on the MBC model, and the 
literature analysis of the Cuban, Chinese and Vietnamese MBC regimes. Sections three, four and five present each of the MBC case studies, and how they relate to the stipulated hypotheses and their independent variables. Section six summarizes the data presented in each of the case study sections, and offers a conclusion on the research question.

\section{Variables and Hypotheses}

The dependent variables of this study are the growth of military involvement in the Cuban economy, and the decrease of military involvement in the Chinese and Vietnamese economies. The dependent variables are measured by counting the increasing or decreasing numbers of FAR, PLA and VPA managed enterprises and industries during the longitudinal existence of the MBC in these three cases. There are three principal hypotheses, with their respective independent variables, that are operationalized and analyzed as possible explanations for the dependent variables.

\section{A. Corruption Variable and Hypothesis 1 (H1)}

James Mulvenon presents the first variable with his study on the PLA. He states that the Chinese PLA military institution was removed from its business role because of high levels of illegal actions within the military enterprises. These illegal activities included organization and financing of drug smuggling operations, illegal construction projects and tax fraud businesses by PLA military units and personnel (Mulvenon 2001). Mulvenon argues that this form of corruption differed from the traditional acts of corruption previously witnessed in the PLA, which compared more to isolated acts of “gift giving,” nepotism and abuse of power to grant special privileges. This new form of 
corruption was centered more on military units and enterprises acting as a collective body. It became so widespread within the ranks of the PLA that, by 1992, military corruption cases had skyrocketed to almost 400 disciplinary hearings involving RMB ${ }^{1}$ 150 million (\$22 million) in allocated revenues (Mulvenon 2001, 142). This form of corruption was uniquely money-oriented. For example, the most conservative estimates of revenue divergence by PLA units were approximately from \$146 million in the early 1990s to \$36 billion around 1997 and 1998 (Mulvenon 2001; and Cheung 2001, 181). Hence, an important attribute of this form of corruption is that it involves a high number of military corruption cases which cost the central government a net loss of billions of dollars in economic profits (Mulvenon 2001). This is the criterion that this study follows in measuring military economic corruption.

For the purpose of this study, corruption within the military is defined as large numbers of military units and personnel financing illegal businesses, and costing the central government amounts exceeding $\$ 1$ billion in economic revenue. This study investigates whether such corruption is rampant in all three of the MBC case studies. The hypothesis is stipulated as follows: if there are negligible levels of corruption within the Cuban military and rampant levels of corruption in the Chinese and Vietnamese militaries, then this variable can offer an explanation for the discrepancies witnessed in the three MBC regimes.

\footnotetext{
${ }^{1}$ RMB: Renminbi, official Chinese currency.
} 


\section{B. Communist Party Variable and Hypothesis 2 (H2)}

The ability of the central communist party to maintain control over the military is a crucial factor that determines the fate of the MBC regime. The VCP is documented to have strong institutional control on the military. According to Thaveeporn Vasavakul, this is a critical component that prevents the Vietnamese MBC regime from expanding, as the local communist party apparatus maintains the number of military enterprises at below 200 units (Vasavakul 2001). This is another hypothesis that is tested and validated in all three of the MBC case studies.

There is one contradicting argument, however, that needs to be explained and accounted for. Various scholars argue that communist socialist regimes do not have clear distinctions between civilian and military institutions, as may be the case in democratic governments such as the United States and the European Union (Perlmutter and LeoGrande 1982, 782). This is so because the armed forces in communist societies are normally active in the political affairs of the local communist party and vice versa. This is not to suggest that there is an absence of areas where a distinction can be made between party and military, but that it is sometimes difficult for a researcher to distinguish between the two institutions, as well as make a determination of which is the more influential of the two actors (Perlmutter and LeoGrande 1982). For this reason, this study takes into account two control measures which are stated to be crucial for a totalitarian authority to oversee and maintain a subordinated military.

Samuel Huntington points to the first factor in his explanation of the term Subjective Civilian Control of the military. Subjective control over the military is when a civilian faction maximizes its power over the military by not allowing the establishment 
of an independent or autonomous military sphere of interest (Huntington 1957, 84-85). Huntington argues that in this type of civilian control, totalitarian regimes rely on interior security ministries, or other control instruments, to maintain or coerce the armed forces into a subordinate role. Such control institutions are analyzed in this study in terms of strength and influence within all three MBC regimes.

Amos Perlmutter and William LeoGrande present the second factor in the shape of "historical legitimacy" within the communist party. They argue that the armed forces stay loyal and subordinated to the local communist party by respecting the historical legitimacy the party holds in society (Perlmutter and LeoGrande 1982, 786). According to these two authors, it is important for communist party apparatuses to begin to build their legitimacy during the time of their formations, which in many socialist regimes occurred through violent uprising and revolution. They argue that during the time of "national revolution,” the communist party organization builds a mutually beneficial relationship with the armed forces, and establishes itself as the leading organizing entity. As such, by the time of "revolutionary triumph," the armed forces see the party as the legitimate government and organizing body (Perlmutter and LeoGrande 1982, 786). On the basis of these arguments, the current investigation conducts a historical analysis of the times during which the respective three communist parties came to power.

Based on these two factors, communist party control over the military is defined as oversight institutions that enable the civilian government to oversee the military establishment, and historical legitimacy which the party possesses to legitimize its authority. The hypothesis of interest is the following: If the Cuban communist central authority does not have control over the FAR, in the shape of institutional control as well 
as historical legitimacy, and the Chinese and Vietnamese party authority do have control over the PLA and VPA institutions, then this variable can offer an explanation for the discrepancies witnessed in the MBC regimes.

C. Bureaucratic-Authoritarian Variable and Hypothesis 3 (H3)

The bureaucratic-authoritarian hypothesis is based on a different notion than the first two hypotheses. It encompasses the possibility that some of the MBC case study countries are adapting qualities that go beyond the traditional MBC model, and can be more accurately explained with an alternative model on military praetorian activity. The alternative model that is analyzed is the Bureaucratic-Authoritarian (BA) model which was applied to various South American military junta governments during the 1960s and 1970s.

A key element in the BA model is that the military becomes the central governing institution and builds a coalition with civilian technocrats who have the skill and education needed to manage the national economy. The BA form of military governance involves a bureaucratic military institution, with many military officers holding delegated positions of power while not being dependent on the authority of a single individual (Collier 1979, 368). As such, the BA form of military governance stands apart from other forms of military rule because of its institutional and decentralized nature of bureaucratic and governing functions. For the purpose of this study, the BA variable is defined as a bureaucratic military leadership, consisting of many military officers holding delegated positions of power and authority. 
The analysis of this variable and hypothesis is done by observing the governing leadership structures of the selected case study countries during the time of MBC regime existence. This involves identifying the key decision-makers of each country, and presenting the institutions and delegates involved in carrying out economic and political policies. As such, an analysis of political leaders and their delegations of authority validates whether there is a delegation of power to civilian or military officers, and accounts for military officers who take active decision-making within the economic and political sectors. Sources such as the Political Handbook of the World are used to present information on the heads of state of each country case study, and their relation to the military apparatus.

The hypothesis stipulates that if prominent FAR military officials hold autonomous or independent institutional positions of leadership, and such military elites are absent in the PLA and VPA cases, then this variable can offer an explanation for the various outcomes observed in the MBC regimes. The BA argument is not aimed at suggesting a complete transformation of Cuban, Chinese or Vietnamese military structures to a BA regime, but to examine the possibility that certain elements from the BA model can account for the fluctuation in outcomes observed in MBC regimes.

\section{Comparative Methodology and Research Design}

Because of their common socialist background, the Cuban, Chinese and Vietnamese case studies present a good comparative opportunity for studying the MBC model. Each of the hypotheses presented is tested on a comparative basis between all the counterpart military institutions. If the Corruption Variable (H1) and the Communist 
Party Variable (H2) are evident in both the Chinese and Vietnamese MBC regimes, but absent in the FAR case study, then both variables can be deemed as possible reasons for the increasing and decreasing MBC regimes. The BA Model Variable (H3) is similarly accounted for in all three case studies. If the BA Model variable is absent in the Chinese and Vietnamese examples, but present in the Cuban contexts, then such is an applicable solution to the research question.

\section{Justification for Research Technique}

The comparative approach is the preferred research method in this study. Scholar Arend Liphart presents additional research techniques that could have been considered in this thesis, but were not deemed compatible with the components of this study. According to Liphart, the three basic research approaches in establishing relations between variables are the comparative, the experimental and the statistical methods of analysis. The experimental and statistical methods are not compatible with this study because of the difficulty in answering the stipulated research question with a controlled experimental or statistical investigation (Liphart 1971). Hence, the dependant and the independent variables that are used cannot be quantified and analyzed in an experimental and statistical manner. Liphart reminds the reader that the best research approach in any investigation is one that combines two or all three research techniques. Yet, he still confirms that the comparative approach is typically the most appropriate technique when dealing with social and political fields of study, especially because political fields of study deal more with qualitative observations instead of quantified data (Liphart 1971). 
However, there are weaknesses of the comparative approach that need to be addressed. One drawback is that most comparative investigations tend to have an exceedingly high number of variables in relation to a limited number of case studies (Liphart 1971). This is because it is often more difficult to find compatible case studies than independent variables that can offer possible solutions to the research question. In the contexts of this study, it is easier to find multiple reasons for the increase/decrease of MBC regimes, than to find compatible case studies to use in the comparative research method. Therefore, this study is limited to an examination of three independent variables to compare consistently with the Cuban, Chinese and Vietnamese case studies.

The second, and perhaps the most important flaw related to the comparative approach is the "fallacy of attaching too much significance to negative findings" (Liphart 1971, 686). According to Liphart, Johan Galtung refers to this weakness when hypotheses and variables directly relate to a lone case study. The study runs the risk of invalidating a hypothesis on the basis of a negative result attributed to a single case study (Liphart 1971). This is one flaw that is addressed in this thesis. For example, H1 is derived specifically from Mulvenon’s arguments on the Chinese PLA case study. Hypothesis 2 is likewise derived from Vasavakul's analysis on the Vietnamese VPA example. To solve this issue, this study employs Liphart's recommendation of integrating certain components of the research design to increase the experimental validity. Thus, all three country case studies are used for testing and analyzing each of the three hypotheses. The analysis then takes into consideration whether all hypotheses come out positive or negative for any of the case study countries, instead of relying on the use of a single country example for analysis. 


\section{Section II: Background and Literature Analysis}

Background on the Military Business Complex Model (MBC Model)

James Mulvenon first isolated the MBC model in his analysis of the PLA and its endeavors in the Chinese business sector from 1978 to 1998 . He briefly explains how the Chinese MBC model was replicated by the Vietnamese and the Cuban military establishments. These countries also proceeded to use their military institutions to increase military revenues, as well as sprout positive economic performance (Mulvenon 2001, 5).

Mulvenon specifically focused on the Chinese MBC because of high levels of military participation in the economy, which reached an approximate number of 20,000 enterprises by 1983 (Mulvenon 2001). For the purpose of this study, Mulvenon’s work constitutes the bulk of the theoretical part of the MBC model.

The MBC practice of involving the military in managing the economic sector is traditionally a continuation of established military protocols. These traditional protocols constitute self-sufficient practices by military institutions, and pave the way for the autonomous nature attributed to $\mathrm{MBC}$ regimes. The rise of the $\mathrm{MBC}$ regime occurs when the already-instituted military protocols are re-structured to serve the civilian population, thus no longer making the military the single consumer of these services. This attribute distinguishes the MBC model from other examples of military praetorian practices (Mulvenon 2001).

A second attribute of the MBC is that it begins with the agricultural sector of the economy. Military institutions in a pre-MBC scenario tend to be active in the agricultural sector by producing grain and food for military personnel. MBC regimes emerge when 
agricultural services start producing for civilian consumption, instead of solely for the military (Mulvenon 2001).

Most MBC regimes also tend to expand across a wide range of industries by emerging first in the agricultural sector, where services go from military orientation to civilian, and then expanding to larger businesses such as hotel lines and restaurants. Many MBC regimes can also expand to a more advanced stage where large profitable industries, such as telecommunications, tourism and public transportation, fall under military management. As such, the military become an important decision maker within the economic and social sectors (Mulvenon 2001).

In light of the Cuban, Chinese, and Vietnamese experiences with the MBC model, a specific trend that arises is that the military becomes a private class in alliance or as a subordinate to the central communist party authority. The military takes a role in the management of the economic sector with the blessing of the communist authority, normally as a response to an economic crisis or threat that could be solved by having the military financially support the civilian economic sector. For this reason, the military acts as an autonomous entity within the arena of communist governance by lessening the financial burden on the communist party and government (Mulvenon 2001).

Having the military as an autonomous actor, however, opens the door for complications within the military institution and its function, mainly in the form of collective and individual corruption cases. These acts of corruption lead to high levels of disciplinary incidents within the military, and in time financially threaten the central communist authority with a large loss of revenues. As military personnel traditionally do not have the business integrity and acumen to manage profitable economic enterprises, 
corruption problems emerge in the shape of high loss of revenues and illegal activities by military units. This is an expansion of general military corruption, which goes beyond typical cases of "gift giving" and abuse of power for special privileges. Overall, with the lack of technocratic skills in economic and business management within the military, the MBC regime often leads to mixed levels of economic performance, creating loss of support and eventual restructuring or even removal of the military from the economy (Mulvenon 2001).

\section{Literature Analysis on the MBC Case Studies}

As stated before, Mulvenon established that the Chinese MBC regime emerged when the PLA military apparatus began the management and funding of economic industries in order to lessen the financial burden on the central government and the communist party. However, complications with the Chinese MBC regime increased when the PLA became so autonomous that it began to set up corrupt and illegal businesses. This involved massive participation of military units, high losses in revenues to the Chinese central government, and overall damage to military discipline as well as military efficiency (Mulvenon 2001). Hence, Mulvenon states that the Chinese MBC regime was eventually dissolved in the late 1990s due to loss of military professionalism and discipline.

Thaveeporn Vasavakul conducts a similar analysis on the Vietnamese MBC, which began when the VPA undertook its economic role in 1986 under the Doi Moi economic reforms. Vasavakul argues that the VCP maintains a sophisticated network of oversight institutions on the Vietnamese MBC, thus preventing cases of military 
Bonapartism ${ }^{2}$ and corruption that were evident in the Chinese MBC (Vasavakul 2001). Vasavakul also states that the VPA is unable to expand in the number of industries due to the existence of other state owned and private enterprises that prevent the VPA from being the only actor within the Vietnamese economic arena (Vasavakul 2001).

Carlyle Thayer, who conducted his own work on the VPA economic endeavor, also acknowledges the institutional control played by the VCP on the VPA. Thayer presents how, in the initial years of VPA economic existence, the Vietnamese military took on its economic mantle by recognizing VCP party oversight and control. Thayer argues that the Vietnamese MBC regime did not lead to independent or rebellious actions by the VPA, due to strong party oversight (Thayer 1994). Thayer later established in the late 1990s that VCP control was weakening, and that future military independent action from the VPA was growing with the naming of VPA official Le Kha Phieu as Party General Secretary (Thayer 2003, 92-93). Yet, this argument lost much of its weight as Secretary Le was removed from his post, and replaced by a civilian party official.

Vasavakul, Thayer and Mulvenon all present reasons for why the Chinese and Vietnamese MBC regimes have not expanded in their domestic economic sectors. They also present the importance of having a communist party apparatus that can control the military and prevent or rectify acts of corruption.

Canadian military officer Hal Klepak explains why the FAR military institution has increased its involvement in the management of the economy, and why the Cuban example does not resemble the norms seen in the Chinese and Vietnamese counterparts.

\footnotetext{
${ }^{2}$ Vasavakul defines the term Bonapartism as a case of military strongman threatening or challenging the civilian government (Vasavakul 2001, 337).
} 
Klepak explains that the FAR follows a mainstream of anti-corrupt behavior, thus preserving a degree of professionalism and military discipline. He does not suggest that there is absolutely no corruption in the FAR's economic presence, but that it pales in comparison to the corruption levels observed in other communist and Latin American militaries (Klepak 2005, 98-99).

In addition to Klepak’s argument, Latin American specialist Frank O. Mora claims that the Cuban Communist Party $\left(\mathrm{PCC}^{3}\right)$ emerged from the FAR, and is locked in a fused type of party-military relationship. This type of relationship has no known distinction between party and military jurisdiction, and involves having a FAR institution that both belongs to the PCC and still exercises control over the institution. Based on this fact, Mora argues that the FAR is the sole decision-maker in its economic business existence, and can protect itself from PCC intervention (Mora 2004, Business).

Juan Carlos Espinosa agrees with Mora’s argument. Espinosa argues that the Cuban revolutionary government is more centered on nationalism rather than on socialist ideological tendencies, which are more prevalent in the Chinese and Vietnamese examples. Espinosa presents this argument to explain why the FAR, not the Economic and Commerce Department of the PCC, was chosen by the Castro brothers to lead the economic recovery during the beginning phases of the Special Period in $1992^{4}$. Because of this fact, Espinosa argues that the legitimacy of the PCC does not match that of the FAR, hence making the FAR the most credible institution in managing the Cuban economy (Espinosa 2003).

\footnotetext{
3 PCC: Partido Comunista de Cuba, or Cuban Communist Party

${ }^{4}$ The Special Period, or Periodo Especial, is commonly known as the beginning of phase of Cuba's economic decline, which was caused by the break up of the Soviet Union.
} 
Klepak, Mora and Espinosa all present possible arguments for why the Cuban military has continued to expand into the economy. Yet these explanations, including those presented by Mulvenon, Thayer and Vasavakul, fall back on theoretical views derived from research conducted on communist-oriented regimes. They do not take into account that these case studies may be adapting norms and tendencies that exist outside of the MBC and communist arenas.

For this reason, the present study applies the third hypothesis of the BA model. Guillermo O’Donnell first documented the BA model in the military governments of Brazil (1964) and Argentina (1966). The BA model was eventually expanded to include countries such as Uruguay and Chile ${ }^{5}$ in 1973, and Argentina again in 1976. According to O'Donnell and Collier, the BA model constitutes an authoritarian government with the military as the principal governing institution ${ }^{6}$. As such, the BA hypothesis can help establish if the FAR military apparatus has grown to a point that it acts as an independent governing institution, and if the PLA and VPA have not grown to such a point in military governance.

\footnotetext{
${ }^{5}$ This case of bureaucratic-authoritarianism refers to the military government of Augusto Pinochet in 1973. See "The Rise and Fall of Bureaucratic-Authoritarianism in Chile" (Ma 1999).

${ }^{6}$ O'Donnell also argued that the BA regime emerged to repress leftist movements and protect the capitalist system. A note here is made to remind the reader that the use of the BA variable and hypothesis is not aimed at classifying Cuba, China and Vietnam as BA regimes.
} 


\section{Section III: Chinese MBC}

\section{Corruption Variable}

The Chinese MBC began with a few farms and factories under PLA control in 1978, and grew to a multi-billion dollar enterprise of 20-30,000 industries in the mid1980s. Various institutions were established to help financially manage the increasing military budget that stemmed from the military economic industries. The General Logistics Department Finance (GLD Finance) was one of the institutions that helped the CCP audit thousands of military enterprises (Mulvenon 2001, 80). It consisted of having audit units to help monitor the flow of revenues that were made in the PLA business dealings.

In the mid-1980s, GLD Finance began to notice large gaps between reported and actual revenues of many PLA-run industries. Large amounts of earnings began to disappear into offshore bank accounts of high-level personnel within the PLA industries (Mulvenon 2001, 143). The Chinese government began to notice and report on large amounts of revenues being used by PLA industries to finance illegal activities, such as money laundering, tax evasion, unauthorized building of hotels and offices, and drug smuggling. By the late 1980s, GLD Finance determined that approximately more than 2.8 billion RMB ( $\$ 416$ million $^{7}$ ) was being used by PLA units to help finance collective, as well as individual, illegal businesses and actions. A 1991 GLD audit of military units at the regimental level established that approximately 1.05 billion RMB (\$148 million) was being withheld by military units in undelivered taxes, 1.04 billion RMB in outstanding

\footnotetext{
${ }^{7}$ This is an approximate conversion using the current exchange rate of the Chinese Central Bank.
} 
loans and 1.05 billion RMB in illegal bank accounts (Mulvenon 2001, 141). GLD

Director Zhao Nanqi expressed this situation in an All-Army Logistic Work Conference.

In light of the country's national condition, our army's condition, special economic circumstances, and the contradictions of supply, the military's production and business operations cannot be expanded and cannot shrink. At the same time, the status quo cannot be tolerated (Cited in Mulvenon 2001, 98).

In 1993, the number of military industries rose by 25 percent, totaling almost 25,000 industries (Mulvenon 2001; and Mora 2002, 190). Disciplinary hearings of PLA officers also increased to 150 - 400 cases of economic corruption per year (Cheung 2001, 175). This symbolized a shift of military corruption within the PLA from average "gift giving” and abuse of power, to a more money-oriented form of corruption (Mulvenon 2001).

By 1995, corruption within the Chinese MBC extended to the point that resources and supplies were also being used illegally by PLA personnel. Military supply trucks and navy boats began to be commandeered by PLA units to help smuggle and sell products for illegal transactions. These operations included selling and smuggling automobiles, refrigerators and other large commodities, as well as drug smuggling to and from mainland China along its southern border with Vietnam (Mulvenon 2001, 149). Critical petroleum resources also began to be sold in the black market, and involved the use of military vehicles for transportation to foreign and domestic buyers in East-Asia (Mulvenon 2001, 145-147).

Many party and military officials began to express concern over PLA military effectiveness, stating that Chinese military involvement in the economy was diminishing combat effectiveness and military discipline. These concerns intensified with events such 
as the fall of communism in 1989 and the demonstration of superior military technology by the United States in the Persian Gulf War in 1991 and in the NATO led bombing campaigns against Serbia between 1995 and 1999. As such, the prospect of a technological war with the U.S. emphasized the need to have a combat-ready PLA institution (Mora 2002).

By the late 1990s, concerns of military efficiency led the PLA economic presence to begin to outweigh its benefits and usefulness. In a 1998 CCP anti-smuggling conference, former President Jiang Zemin stated that the government defense budget should be the only source of finance used by the PLA. At which point, party political support began to enforce a rectification campaign on the military. It was here then that the Chinese leadership ordered the removal of the PLA from the Chinese economy (Mulvenon 2001).

Such a calculated move took two years to be completely implemented. Between 1998 and 2000, all PLA military businesses were dismantled or redistributed to civilian and party management. A number of industries that were deemed crucial for military applications were allowed to be left under military jurisdiction, yet this number did not exceed more than 1,000 factories and were mostly centered on producing weapons and munitions (Mulvenon 2001). The enforced removal of the PLA from the economy was so severe that by the year 2000, almost $85 \%$ of the PLA economic units had been dissolved and eliminated. 


\section{$\underline{\text { Communist Party Variable }}$}

The PLA and the CCP were both created in 1927 under the communist leadership of Mao Tze-tung. Mao acted as supreme leader for both institutions, and his initial proclamation as chairman of the CCP helped establish party legitimacy within the armed forces, as well military obedience to his charismatic decision making (Joffe 2006, 13).

By the late 1920s, the political commissar system was installed in the PLA. Party officers began to accompany PLA units and ensure party doctrine in military decision making. However, this triggered resistance by field commanders who were fighting the KMT nationalist forces in central and eastern China during the $1930 \mathrm{~s}^{8}$. Their main argument was that civilian political officers were interfering with day to day decision making in the PLA chain of command. The political officer system was removed in 1936, and Chairman Mao ensured that all political and military decision making passed through him (Ji 2006, 92). His authority was formally institutionalized in 1951 with the creation of the Central Military Commission $\left(\mathrm{CMC}^{9}\right)$ under the leadership of the CCP (Ji 2006).

The party commissar system was re-introduced in 1958 due to cases of criticism from PLA generals and officers on party leadership. The re-introduction of the commissar system installed political commissars on all branches of the PLA, including the Air Force, Navy and regular Army units (Shirk 2007). The system was later partially removed in 1976, yet the need for reliable oversight of the PLA was not eliminated. A system of party secretaries was installed under the new leadership of Deng Xiaoping in

\footnotetext{
${ }^{8}$ For more information on Mao Tze-tung and the Chinese civil war of 1927-1949, see Uncertain Partners: Stalin, Mao and the Korean Wa (Goncharov et al. 1993)

${ }^{9}$ To this day, the CMC is still the main liaison body between CCP and PLA decision making, and is the most active institution overseeing PLA enterprises and businesses.
} 
1985. Party secretaries were known to report on PLA actions and decision making to the leadership of the CCP. However, they did not have the authority granted to political commissars on actively overruling PLA officers and their decisions. Sole authority of overruling military decision was reserved only for Chinese leader Deng, the CMC, and by party member vote in the Central Committee of the CCP (Ji 2006).

In 1993, President Jiang Zemin, a civilian official, began to enforce party secretaries at the provincial level by giving them the status of political officers. The new batch of commissars was composed of both civilian and military personnel, ensuring active participation of political commissars and secretaries answerable to the CMC and preferentially acceptable to both CCP and PLA interests (Ji 2006, 94-95). Such a network of civilian oversight has been prevalent in Chinese party-military relations ever since.

\section{BA Model Variable (Military Institutional Rule)}

The communist government of China has historically been led by four prominent leaders. The leadership under Mao Tze-tung lasted from 1927 up to his death in 1976, and involved a central form of leadership where Mao was considered head of the party and the military, and all decision making was based on his authority with little or no criticism by PLA officers (Joffe 2006). For example, the re-installation of the political commissar system in 1956, and the removal of Minister of Defense Pend Dehuai during the "Great Leap Forward" in 1958, were both accepted by the PLA with limited criticism and resistance (Joffe 2006, 13).

Mao was also hesitant in delegating authority to any of his subordinates. He was very much the main decision maker in all civilian and military matters, and he constantly 
warned over having too much bureaucracy and decentralization of power (Banks et al. 2008). He did possess an entourage of trusted advisors whom he appointed to various positions within the CCP and the CMC. Some of these included political commissars Ji Dengkui stationed in the Beijing Military District, Ma Tianshui in Shanghai Military District, Mao Yuanxin in Shenyang Military District, Zhang Chunqiao in the General Political Department (GPD), and Wang Hongwen in the CMC. By serving as chairman of both the CCP and the CMC, Mao ensured that his network of advisors would keep him updated in all PLA decisions, thus ensuring his centrality in both institutions with limited delegated authority (Ji 2006, 13-14).

Mao’s successor, Deng Xiaoping, also employed a network of party and military advisors that ensured his leadership, most notably CMC Vice-Chair Yang Shangkun. Deng was able to solidify his power between 1976 and 1978 by purging the pro-Maoist “Gang of Four”, as well as Mao’s former wife Jiang Qing (Banks et al. 2008, 249-250). In the 1980s, Deng began to institute economic reforms, which involved helping save costs on the central national budget. These new economic policies included severely diminishing the national defense budget, as well as cutting the number of active regular PLA troops. Yet, to offset the diminishing defense budget, Deng ordered the PLA to begin increasing their economic activities, thus constituting the initial beginning of the Chinese MBC (Mulvenon 2001). Despite some isolated instances of resistance and hesitation by PLA elements in pursuing military economic policies, Deng's establishment of political secretaries, as well as his authority as leading chair within the CMC from 1978-1989, ensured that his decision to increase PLA presence in the economy was followed by the PLA officer’s core (Mulvenon 2001). 
It is important to note, that both Mao and Deng were known as central figures in managing institutions such as the CCP, the CMC and the PLA. Both were known as charismatic leaders who held maximum authority within the CCP and the CMC, and both possessed legitimate authority within the PLA as respected leaders during the Chinese revolutionary war (1927-1949). Hence, limited delegation of decision making was evident during both their times in power ${ }^{10}$ (Joffe 2006, 12-14).

Deng’s leadership lasted until 1994, when he seemingly disappeared from public life. Jiang Zemin, former chairman of the $\mathrm{CMC},{ }^{11}$ was then named as his successor. Jiang's rise to power in the mid-1990s symbolized a shift in Chinese leadership and military management. Apart from Mao and Deng, which had strong roots within the PLA, Jiang was completely a civilian leader with no military experience, as well as limited charismatic appeal. His leadership was thus carried out by strengthening institutions, such as the CCP and the CMC, instead of falling back on charismatic legitimacy that was evident in his two predecessors (Joffe 2006, 15-17). This was done by replacing both older civilian and military officers with younger officials that supported his rule. This included the removals from the CMC of Generals Yang Baibin in 1992, Liu Huaqin, and Zhang Zhen in 1997, all of whom were deemed by Jiang as too independent and threatening to his rule (Ji 2006, 100).

His policies were then followed by President Hu Jintao in the early 2000s. Hu was also a civilian party official with limited military legitimacy, and relied on strong

\footnotetext{
${ }^{10}$ See also Political Handbook of the World 2008 (Banks et al. 2008).

${ }^{11}$ Jiang was the first known civilian chair of the CMC. He obtained such a position when Deng Xiaoping relinquished his formal title of Chair of the CMC. After which, Deng possessed informal rule of the CMC, and was still recognized as China’s supreme leader (Banks et al. 2008, 252)
} 
institutions to ensure his rule. This reliance was strengthened in 2005 as he gathered enough political support from the CCP to oust former President Jiang ${ }^{12}$ from the CMC chairman position, a position that President Hu then took for himself (Joffe 2006, 17).

Presidents Hu and Jiang were not the central charismatic leaders seen in Mao and Deng. They were more bureaucratic in nature, as both of them relied on institutional strength from the CCP and the CMC, in contrast to Mao and Deng, who relied more on their strong character and legitimacy to rule. Yet, neither of these presidents, including Mao and Deng, delegated authority to military leaders to the point seen in BA regimes. They all had their circle of advisors, and in the case of Presidents Hu and Jiang, a decentralization of institutional authority did occur in the shape of the empowered institutions of the CCP and the CMC (Joffe 2006). These examples are based more on a civilian bureaucratic authority, and do not match the BA regime form of military delegated authority presented by Collier and O'Donnell. This comparison of militarybureaucratic BA regimes and the Chinese $\mathrm{MBC}$ is further analyzed in the last section of this study.

\footnotetext{
${ }^{12}$ President Jiang retained his post of chairman of the CMC after he relinquished the presidency in the year 2003 (Joffe 2006, 16-17).
} 


\section{Section IV: Vietnamese MBC}

\section{Corruption Variable}

The case of financial corruption within the Vietnamese MBC is not as compelling as the Chinese example. The most evident case of corruption was reported in 1997, when the Chinese communist authority was beginning to undertake its plan to remove the PLA from its business mantle. In interviews conducted with PLA officers stationed in Beijing, Vietnamese military units were implicated in smuggling automobiles and other commodities from China into northern Vietnam. These actions took part within the Chinese MBC corruption context, and ensured VPA cooperation with PLA units in the illegal smuggling businesses (Mulvenon 2001, 149).

Other cases of Vietnamese corruption within its MBC structure were reported in 2008. According to the Washington based non-profit organization Hmong National Development, VPA units were involved in illegal logging in neighboring Laos to harvest wood and timber. Such materials were then processed and used to produce furniture and materials for construction projects, and also sold in international markets by VPA managed companies (Hmong 2008). Yet, these reported cases of corruption and theft within the Vietnamese MBC structure have only been sparingly acknowledged by the Vietnamese civilian and military leadership. It is not clear whether these acts are condemned or sanctioned by the VCP, as it is also not clear whether these acts resulted in a high net loss of revenue for the governing VCP, as per the corruption definition of this variable.

Other examples of corruption have been generally referred to by state media. In the years between the eighth and ninth national party congresses (1994-1997), 
Vietnamese news agencies and media centers such as Nhan Dan stipulated that corruption and illegal smuggling by both party and military officials was the main internal security threat to the state of Vietnam (Stern 1998, 18-22). Hence, general corruption could very well exist in the Vietnamese MBC, yet there is no evidence to suggest that it has expanded to the sophisticated network witnessed in the Chinese MBC, which cost the central government billions in economic revenues.

\section{Communist Party Variable}

The VPA was created in 1944 by party leader Ho Chin Minh, as a parallel institution to the Indochinese Communist Party (ICP). Minh saw the need to train and create a fighting force of Vietnamese nationalists to help unify the Vietnamese nation, which had contended with Japanese imperialism in the 1940s and French colonialism in the 1950s. It was first composed of approximately 500 fighters in 1945, but grew to a number of more than 10,000 troops by the mid-1950s (Vasavakul 2001, 336).

The Vietnamese Communist Party first began as the ICP in 1944 under the leadership of Ho Chin Minh. It was then renamed the Vietnamese Workers’ Party (VWP) in 1954 and then the Vietnamese Communist Party (VCP) in 1976 as the official government party of the newly unified Socialist Republic of Vietnam (SRV) (Banks et al. 2008, 1477). During its initial years, the party mostly followed the decisions employed by leader Ho Chin Minh. Ho surrounded himself with individuals who had dual roles in forming the communist party apparatus, as well as the Vietnamese military institution. These included individuals such as General Secretary Le Duah, Army General and party founder Vo Nguyen Giap and civilian Vice-Minster of Defense Song Hao. All of these 
individuals played dual roles in the party and the military during the formation years of both institutions. These dual role personnel ensured parallel military and party compliance, as well as party historical legitimacy over the armed forces. Ho's early proclamation in 1944 of the Vietnamese revolution as a socialist revolution under the leadership of the ICP also ensured party historical legitimacy in the VPA military institution (Vasavakul 2001, 341).

After the successes of driving out France in the 1950s and the United States in the 1970s, certain institutions were installed to help manage and oversee the VPA, which by then was composed of almost 2 million soldiers. Institutions such as the Central Military Party Committee (CMPC) and the General Political Directorate (GPD) were created in the mid-1980s to help party agencies implement policy and directives in the VPA.

The CMPC was established in 1985 and was the latest institution of a long line of preceding party institutions, which included the General Military Committee (19531961), the Military Party Committee (1961-1982), and the Military Council (1982-1985) (Vasavakul 2001, 341). The CMPC was the main liaison institution that ensured party commissars within the VPA followed party decisions and policies. It also kept tabs and records of military personnel that were party members to ensure party compliance by military officials (Vasavakul 2001, 341-344).

In the early 1990s, the CMPC mandate was expanded to include oversight on the Vietnamese MBC. In 1994 and 1997, it enforced two separate VCP reforms which were meant to increase effectiveness in Vietnamese military enterprises. These reforms led to the diminishment of military enterprises from 300 industries to less than 200 units; an act that was severely criticized by VPA military leaders (Thayer 2003, 89-92). 
The GPD was established in 1981, and was set up under the Ministry of Defense, yet it specifically took orders from the VCP Central Committee. The GPD was specifically responsible for propaganda and ideological education within the VPA. It consisted of publishing newspapers and producing films for young military recruits (Vasavakul 2001, 343).

The system of party oversight institutions has kept strong controls on the VPA military apparatus; however, the argument must be made that this system has not exempted the VCP from military criticism. Various generals and officer from the VPA, including former Secretary Lt. General Le Kha Phieu, openly criticized the party in the preceding months of the eighth party congress in 1996. In his address over the Hanoi National Radio Network, Secretary Le openly stated that the VCP needed to do more to increase training and education of raw young recruits within the armed forces. He also criticized the party for failing to make industrialization and economic modernization more of a national priority in the 1990s (Stern 1998, 41). General Dao Dinh Luyen, a long standing member of the Party Military Committee, also, criticized the party in an article published by Quan Doi Nhan Dan. Dao stated that the VCP was failing to meet the requirements needed to improve industrialization, technological advancement and national defense (Stern 1998, 42).

The Vietnamese military institution has at times openly criticized the local communist authority, yet these acts of resistance have been limited to simple public criticism. History shows that the VPA has not been able to prevent party action in containing independent military decision making. An example of this is seen with the 
removal of Lt. General Le Kha Phieu as party secretary in the early 2000, which was criticized but otherwise accepted by the VPA leadership (Vasavakul 2001, 351).

\section{BA Model Variable (Military Institutional Rule)}

As discussed, the VCP was originally formed in 1944 as the Indochinese Communist Party by Ho Chin Minh and his circle of civilian and military leaders. This circle consisted of various individuals such as party member Hoang Van Thai, General Secretary Le Duah, Army General Vo Nguyen Giap, civilian Vice-Minister of Defense Song Hao and head of the General Political Directorate Nguyen Chi Thanh. All of these individuals played their own part in carrying out party and military policy, yet the central authority figure that governed the Vietnamese nation was the charismatic party leader Ho Chin Minh (Vasavakul 2001). Minh was the original founder of the ICP and the Vietminh socialist movement, and all party and military authority was centered on his persona with limited delegation of power (Banks et al. 2008, 1478-1479).

Ho’s death in 1969 brought the de facto-leadership of General Secretary Le Duah $^{13}$ until the formation of the SRV in 1976, which then brought the authority of President Ton Duc Thang as the official leader of the SRV (Banks et al. 2008). Ton's leadership is typically characterized with mixed results. Under his leadership North and South Vietnam unified into the SRV, which was Ho's ultimate national goal, yet many scholars argue that his characterization of a charismatic leader was fabricated by party propaganda. Hence, many scholars argue that the main decision maker during Ton's rule

\footnotetext{
${ }^{13}$ The post of President and Party Leader was left vacant until 1976 as a sign of respect to Ho Chin Minh's leadership (Banks et al. 2008, 1478).
} 
was the party member and head of the VPA, General Vo Nguyen Giap (Banks et al. 2008).

Vietnam came under the rule of various leaders after President Ton's death in 1980, yet the SRV was basically run by the sophisticated institution of the VCP, which included the oversight institutions described in the above part of this section. The presidents and political leaders that came after 1980, Presidents Nguyen Huu Tho, Trung Chinh and Vu Chi Cong, were all characterized as non-charismatic and non-military leaders. All three of these leaders mostly focused on strengthening the bureaucracy of the VCP, as well as normalizing relations with Vietnam's neighbors, and establishing steady economic progress (Banks et al. 2008).

It was not until 1992 that Vietnam came under the presidency of its first military leader, retired General Lu Duc Anh. The Vietnamese MBC first began to take hold in 1986, yet it was under Lu’s leadership that it grew to its zenith point of more than 300 industries. Under Lu’s presidency, the most prominent military member that rose to a high position of power was Lt. General Le Kha Phieu. Le was placed in charge of internal security, and made member of the politburo and the CMPC in 1992 (Vasavakul 2001, 350-351). He was also party secretary from 1997 to 2001, until he was replaced by party official Nong Duc Manh. President Lu Duc Anh eventually resigned in 1997, and Vietnam was again under a civilian presidency with the leaderships of Presidents Tran Duc Luong and Nguyen Minh Triet (Banks et al. 2008).

The important argument to note is that the two most crucial presidencies in Vietnamese history were the leaderships of Ho Chin Minh and Tun Duc Thang, both of whom were known more for their civilian political background (Banks et al. 2008). After 
which, with the formal installation of the VCP in 1976, Vietnam was basically governed by the civilian communist party institutions (Banks et al. 2008). The only resemblance of BA model military authority was with the leadership of President Lu Duc Anh in 1992, and the naming of Lt General Le Kha Phieu as Party Secretary in 1997. Another example is that of General Nguyen Giap, who was still influential within the party and military structures of Vietnam during the 1990s. Both of these officers were known to have support for the Vietnamese MBC, and it was during the time these two officers were in power that the number of military industries increased to its zenith point of 300 units. Yet, President Lu Duc Anh resigned as acting president when he was voted out by the National Assembly of the VCP in 1997, and Le was eventually removed from his post in 2001, triggering much complaint by the VPA leadership (Vasavakul 2001, 351-352).

These examples of military decentralized leadership within the Vietnamese MBC do not conform to the arguments presented by O’Donnell and Collier regarding BA regimes. This is so because even during the time of military President Lu Duc Anh, Vietnam was still centrally governed by the local communist party (Vasavakul 2001). This fact is shown with the two economic reforms that were enacted by the CMPC institution on the Vietnamese MBC during the time President Lu Duc Anh was in power. This notion is analyzed furthered in the final section of this thesis. 


\section{Section V: Cuban MBC}

\section{Corruption Variable}

The most public case of military corruption in Cuba occurred in 1988, with the arrest and eventual execution of FAR General Arnaldo Ochoa. Ochoa was one of the FAR's most well known and well respected commanders. He was a veteran of the long and brutal African campaigns that lasted from 1975 - 1989 (Latell 2005, 207-217). He was arrested in 1989 after his return from Angola on charges of alleged drug trafficking. Ochoa, along with Minister of Interior José Abrantes, and MININT agents, Patricio and Antonio de la Guardia, was convicted and found guilty in a public show trial. It was said that Raúl Castro, long time friend of Ochoa, voted to have the ex-FAR General executed (Latell 2005, 207-217) ${ }^{14}$.

Next to General Ochoa, the second most prominent case of corruption within the Cuban military involves Minister of Defense General Julio Casas Regueiro. Regueiro is said to have implemented special privileges and promotions for himself and his staff of officers. As is the case with many other FAR officers, he also has access to the "dollarized”"15 sections of the Cuban economy, as he is co-founder of the all influential

GAESA S.A., group which helps finance the Cuban military apparatus (Mora 2002).

A similar case is also made for FAR General, and head of Copextel S.A., Ramiro Valdés, as well as Raúl Castro’s son-in-law Major Luis Alberto Rodríguez. Valdés has

\footnotetext{
${ }^{14}$ It must be noted that there are various scholars that argue that the Ochoa affair was a move by Fidel Castro to eliminate a potential challenger and rival to his authority. As such, there is widespread debate whether if the Ochoa affair is an accurate example of military corruption.

15 The use of the US dollar is limited by the Cuban government. Only selected stores and sectors of the economy which are managed by the military and the party are allowed to spend in dollars (Espinosa 2003).
} 
been documented to travel extensively to Europe on personal trips based on his status as FAR general. He is also said to own luxurious personal properties in Spain and Austria which are paid for by FAR economic revenue streams (Díaz-Briquets and Pérez-López 2006, 154). Major Luís Alberto Rodríguez, according to articles from the Miami Herald, was placed in the position of Director General of GAESA, thereby indulging in the life of privilege by being son-in-law of Raúl Castro and having access to the important “dollarized” sectors of the economy (Díaz-Briquets and Pérez-López 2006, 144).

Other forms of corruption have taken place in the lower and mid-levels of the FAR economic hierarchy. Cases of overpricing in military-managed retail stores by civilian and military employees have been documented in the late 1990s and early 2000s. Such overpricing entails foreign customers being overpriced in their purchasing of commodities, enabling employees to pocket the difference for themselves (Díaz-Briquets and Pérez-López 2006). Such forms of corruption have occurred in dollar retail stores belonging to corporations Cimex S.A. and TRD Caribe, both of which are under the jurisdiction of the Ministry of the FAR (MINFAR) and Ministry of Interior (MININT) (Díaz-Briquets and Pérez-López 2006). According to the Cuban media network, Cubanet, Gaviotas S.A. was also incriminated in corrupt acts, when two military employees reportedly sold several job positions of taxi drivers and hotel clerks to citizens willing to pay for them (Díaz-Briquets and Pérez-López 2006). Cases like these of overpricing, illegal selling of employment positions, as well as theft, have been recorded all throughout the economic sectors of tourism and agriculture, which are managed by the FAR. 
In the early 2000, cases began to emerge of military officers renting out apartment complexes to foreigners, and evicting the Cuban residents that formerly resided in such apartments (Latell 2005). However, it is not known if such cases of business-transactions are sanctioned by the governing leadership, or are an illegal practice by military officers. No party or military official, as of yet, has claimed that such practice is illegal (Latell 2005).

\section{Communist Party Variable}

The PCC institution was officially created in 1965, but according to LeoGrande was not considered a strong reliable governing organization until the early 1970s. The FAR was created in 1961, yet its personnel and staff were already organized under the leadership of Fidel and Raúl Castro in 1957, eight years before the creation of the Cuban communist party. This lapse of time ensured a party military spectrum that consisted of a newly created communist party organization contending with an already established legitimate military institution (LeoGrande 1978).

In 1961, then President Fidel Castro ordered the creation of the Central School of Revolutionary Instructors. It was created to train and educate a set of revolutionary instructors to help train and politically educate the FAR military units, a move that was part of Fidel Castro's pronouncement of the Cuban revolution as a socialist revolution. With this pronouncement, Castro saw the need to make sure that his FAR troops remained loyal to his regime. Between the years of 1959-1962, the only mechanism of 
civilian control over the military was the loyalty of the FAR forces to Castro himself ${ }^{16}$, and the counterweight offered by the National Revolutionary Militias composed of irregular civilians (LeoGrande 1978, 206). Yet, the establishment of revolutionary instructors, who were later on referred to as political instructors, offered the Castro leadership a more sophisticated institution to maintain civilian control of the FAR.

By 1963, the drawbacks and overall failures of installing political controls on the FAR became exceedingly evident. Cuban military officers immediately began to criticize the use of political officers, arguing that such did not have any knowledge or experience in military governing methods. Military officers also began to complain that political officers were a major impediment in military fighting effectiveness. With the preceding events of the Bay of Pigs Invasion and the Cuban Missile Crisis in 1961 and 1962 respectively, the Castro leadership decided to appease the FAR officers by modifying and restructuring the training parameters of political officers. As such, during the time span of 1963-1970, political officers were strictly limited to act as a supportive role to the military. This included taking direct orders from FAR officers in their respective military units (LeoGrande 1978, 207-210).

A similar outcome occurred with the official creation of the PCC in 1965. Military officers voiced their criticism and concern of creating a bureaucratic institution such as the PCC, stating that such bureaucratic intervention in Cuban politics would impede the FAR's administrative and military mandate in Cuban society. Such conflict of interest was voiced by then Minister of Defense Raúl Castro in 1966, who, according to

\footnotetext{
${ }^{16}$ Edward Gonzáles documents this charismatic element with his Fidelismo model, which presents a charismatic leader holding complete central authority in every single component of governance, as such not relying on any decentralized bureaucratic political institution (Gonzáles 1974, 218-221).
} 
LeoGrande, admitted that there was widespread resistance by FAR officers in accepting PCC command. Because of favoritism, and overall prestige of the military, the PCC was unofficially recognized as a supportive arm and tool of the FAR between the formation years of 1965 and 1970 (LeoGrande 1978, 207-210). During this time, as the inner departments of the PCC were organized and consolidated, FAR officers held almost complete decision-making in selecting members for the party central committees. This also meant that during these initial years, criticism of FAR officers by party members was completely banned during party meetings. Thus, in the formation years of the PCC, the Cuban communist party was completely subordinated to the FAR military institution (LeoGrande 1978).

It was not until the 1970s, that the PCC began to increase its control and influence as a governing institution. This was due in large part to the failure of the 10 million grain harvest to live up to expectations under the mostly military-administrated economic policies. By 1974, the FAR position of privilege in non-military tasks had begun to decrease, and the Cuban party-military spectrum began to resemble the typical communist regimes seen in Russia, Asia and Eastern Europe. However, despite this reversal in party-military relations, they quickly reverted back to a similar scenario of the 1960s with the emerging Gorbachev reforms of the 1980s, and the eventual collapse of the Soviet Union in 1989 (Espinosa 2003). In the 1990s, the Castro regime began to augment the FAR's hold on power by increasing its economic and political influence, which consisted of transferring economic and political institutions from PCC jurisdiction to FAR management (Espinosa 2003). 
The most famous case of transfer of power was the change in jurisdiction of the Ministry of Interior (MININT), the main domestic security institution in Cuba. The Cuban MININT was created in 1961 by Fidel Castro with the original purpose of defending the regime from CIA clandestine operations. Its mandate was then expanded to oversee local institutions. This included having inner components and departments such as the Department of State Security (DSE) and the Group of Special Operations (GOE) to oversee FAR personnel and operations (Rodríguez 1996, 39-41). In 1989, however, with the sacking of MININT director José Abrantes, FAR General Abelardo Ibarra was named as head Minister of MININT. This led to a change in MININT operations and procedures, including FAR participation in security decision-making, inability to investigate FAR officers without prior military approval, and stationing of FAR personnel in security tasks such as interrogations, drug enforcement and crime investigations (Rodríguez 1996, 4249). Hence, the one institution that could have offered oversight on the FAR began to be heavily hindered in military oversight operations.

\section{BA Model Variable (Military Institutional Rule)}

The Cuban leadership structure has always been centered on Fidel and Raúl Castro. Such has been the case since the triumph of their revolutionary struggle in 1959. As was the case with Chairman Mao Tze-tung in 1949 China, and party leader Ho Chin Minh in 1965 Vietnam, President Fidel Castro proclaimed himself in 1959 as the sole charismatic decision maker within the domestic political governance. According to interviews from defected Cuban officials, Fidel himself admitted his deep antipathy for bureaucracies and committee forms of government. He was known to have an inner circle 
of ten civilian and military advisors, including but not limited to Ernesto Che Guevara and Raúl Castro. Fidel took responsibility for all the major decisions in Cuba after listening to advice and recommendations from his advisory circle (Maingot 2007, 8-9). Hence, all authority and decision-making was centered on him and his charismatic persona. This was the main characterization of Cuban governance from 1959 to 2006, before Fidel officially relinquished power to his younger brother.

Raúl Castro, in contrast to his brother, is considered to lack charisma and centrality, as well as assertiveness and prestige within the Cuban context (Maingot 2007, 12-13). In response to this absence in charisma, Raúl's leadership has been characterized as delegating power to specific military officers who were loyal to him during his time as Minister of Defense. These officers are characterized as loyal to the Castro family, and are deemed to operate with autonomy under Raúl Castro’s presidency (Maingot 2007). These officers include generals Ramiro Valdés, Julio Casas Regueiro, and Abelardo Ibarra, who have influential decision-making abilities in their respective fields of authority. General Ramiro Valdés ${ }^{17}$ was former head of the Ministry of Interior in the 1960s, and now heads FAR Corporation COPEXTEL S.A. General Julio Casas Regueiro is considered a key player in managing the all important GAESA S.A. organization, and is considered as the second most important military officer next to Raúl Castro (Latell 2005, 242). General Abelardo Ibarra is currently head of the Ministry of Interior, which was shifted to military jurisdiction in early 1990. These three individuals represent some of the most important personnel in the FAR (Latell 2005, 218).

\footnotetext{
${ }^{17}$ It should be noted, however, that Valdés was considered in the late 1980s as a potential rival to Raúl Castro. As such, his loyalties are stated to be more inclined toward Fidel than Raúl (Latell 2005, 221).
} 
Other personnel include General Luís Pérez Rospide, head of Gaviota S.A., General Eladio Fernández Civic, head of Geo-Cuba S.A., Major Luís Alberto Rodríguez, co-head of GAESA and Raúl’s brother-in-law, and Division General Rogelio Acevedo, head of CACSA S.A. FAR appointments to government ministries include General Ulises Rosales del Toro, head of the Ministry of Sugar Industry, Colonel Manuel Marrero, head of the Ministry of Tourism, General Carlos Fernández Gondin, head of the FAR counterintelligence and vice minister of MININT, Colonel Álvaro Pérez Morales, former head of Ministry of Transport and Ports, and Colonel Orlando Rodríguez Romay, former head of Ministry of Fisheries and Merchant Marine (Amuchástegui 2000). All of these appointments of FAR officials represent the increasing wave of the Cuban military’s economic presence, and symbolize an independent military element within the Cuban government.

It is important to note that many of these officers come from the revolutionary years of the 1950s and 1960s. They were some of the most trusted officers under Fidel Castro's command, and they reported directly to Fidel and his decision-making. It was not until the 1990s and 2000s that these officers began to hold autonomous political and economic decision-making powers. Hence, this institutional form of military economic and political management is an evolving new phenomenon that closely resembles the appointments and delegation of power seen in BA regimes. 


\section{Section VI: Analysis and Conclusion}

\section{Corruption Analysis}

As this study shows, the corruption cases in the Chinese MBC described by Mulvenon are a unique example of military greed that is not accurately manifested in the Vietnamese and Cuban MBC examples. The corruption cases within the Chinese MBC grew to a point where approximately \$36 billion in 1997 was being diverted for illegal businesses and usages within the hierarchical structures of the PLA institution (Cheung 2003, 181). It was a sophisticated network of businesses that involved divergences of state resources, such as military vehicles and petroleum supplies, for smuggling and black market commodity sales.

This form of corruption does not match the decentralized documented cases seen in the Cuban and Vietnamese MBC structures. For the Vietnamese case, despite the fact of references by PLA generals of cross-border smuggling by the Chinese and Vietnamese militaries, there is simply not enough evidence that shows this to be a sophisticated corruption ring involving multiple military industries and units. As far as the evidence is concerned, these acts of corruption within the Vietnamese MBC are decentralized and far from the sophisticated network of corrupt industries seen in the Chinese MBC.

The Cuban case also does not replicate the Chinese example. The argument of FAR generals who have been known for corruption in the shape of special promotions and privileges does not resemble a sophisticated network of corrupt military industries. There are implicit cases of corruption possibilities within the leadership structure of the FAR, specifically the notion of having high level FAR officers possess access to the wealthy “dollarized” sector of the economy. Yet, these implicit examples involving 
officers, such as General Casas Regueiro and General Valdés, still fall under the typical corruption cases of gift giving and special privileges (Klepak 2005).

The examples of lower and mid-level soldiers abusing their positions within the Cuban MBC regime, which includes overpricing commodities as well as selling off employment positions, relate more to general types of corruption seen all across Cuban society as a whole ${ }^{18}$. It is well known that Cuba has been suffering a continuous economic crisis that has impacted all sectors of the population. Scholar David Brown presented the case of two Cuban fighter pilots who defected in 1993 because of the food shortages and rationing of the Special Period. Brown explains that the economic situation in Cuba has also affected the lower and mid-level elements of the military (Mora 2004, Technocrat, 14). Thus, the corruption cases outlined in this study within the non-elitist levels of the FAR are based more on the survival instincts of the Cuban people rather than on the money-oriented form of corruption seen within the Chinese PLA enterprises.

Overall, the corruption cases within the Chinese MBC structures became centered on financial and revenue generation, which are not applicable in the Vietnamese and Cuban scenarios. The corruption hypothesis can help explain the decreasing case of Chinese military-economic involvement and can also explain the increase in Cuban military industries, but it cannot validate why the Vietnamese MBC regime has decreased in economic industries. In conclusion, the corruption variable is only a partial answer for the research question.

\footnotetext{
${ }^{18}$ This statement refers to the arguments made in Corruption in Cuba: Castro and Beyond, (Díaz-Briquets and Jorge Pérez-López 2006).
} 


\section{$\underline{\text { Communist Party Analysis }}$}

According to Huntington, Perlmutter and LeoGrande, totalitarian states ensure civilian control with their governing historical legitimacy, and with the use of security and oversight institutions to penetrate military decision making. The Chinese and Vietnamese communist institutions were both created in their initial years on a simultaneous platform with their armed forces, and they both were given executive rights, through their charismatic party founders, to oversee their respective military institutions. Apart from isolated cases of military personnel criticizing party governance, the Chinese and Vietnamese military institutions as a whole recognized and followed orders from their respective leaders and communist parties (Thayer 2003). Thus, both the Chinese and Vietnamese party organizations possess historical legitimacy within their party-military spectrums, thereby meeting the benchmark of historical political legitimacy.

The Cuban case presents a different example, where the FAR military institution predates the PCC by several years. The FAR military was the main working institution in the 1960s, and was the main managerial agent that took charge of rebuilding Cuban society after the revolutionary war of 1957-1959 (Espinosa 2003). By the time the PCC came to be created in 1965, it had to contend with a well-entrenched military governing regime, which severely limited the legitimacy the party could bring about on the military. Lack of historical legitimacy is clearly seen as FAR commanders had almost complete authority to determine party committee membership, determine issues and projects that could be discussed in central party meetings, and possessed authority to prevent FAR personnel from being investigated and criticized by civilian party leaders (LeoGrande 
1978, 206). Hence, the Cuban MBC case study does not go along with Perlmutter's and LeoGrande’s argument of historical legitimacy.

The argument of security and oversight institutions is also a fact to explain in this analysis. During and after the initial years of socialist revolution, the Chinese and Vietnamese communist parties installed a network of oversight institutions on the PLA and VPA military establishments. Despite initial resistance by army officers in the 1930s, the CCP eventually installed a dual system of political commissars and political secretaries who answered to the Chinese president, the Central Committee of the CCP, and the CMC liaison institution. It was this institutional network that enabled the diminishment of the PLA involvement in the economy in 1998 (Mulvenon 2001). The Vietnamese, likewise, installed a similar chain of institutions which specifically answered to the CMPC in the 1980s. They also possessed a system of political commissars that was modeled on the Chinese and Soviet examples (Vasavakul 2001). The institutional rule of the VCP, as well as the CMPC, ensured two waves of reforms in the Vietnamese MBC, which resulted in the diminishment from 300 VPA military enterprises to less than 200 industries.

In the Cuban example, the attempt at installing political officers in the ranks of the FAR was met with resistance and overall failure in the 1960s. Despite the apparent success by the PCC after 1974 in becoming a legitimate institution with central committees to offer oversight on the FAR, the economic crisis which began in the 1980s, and intensified in the 1990s, opened the door for the FAR to act, once again, as a power broker above the PCC. Party weakness in overseeing the FAR also became evident when the Ministry of Interior was transferred to military jurisdiction in 1989. This led to FAR 
participation in MININT operations, including interrogation and investigation procedures, and most importantly to prohibition of investigations of the military without FAR approval (Rodríguez 1996).

The fact that the Chinese and Vietnamese communist parties maintain an oversight institution on their respective militaries, as well as a system of party political officers, shows that they meet Huntington's argument of use of security and oversight institutions to maintain party dominance over the military. The Cuban example, however, does not meet Huntington's argument on grounds that the FAR has historically resisted PCC control, and presently controls the main security institution that could offer party oversight. Thus, the Cuban party-military spectrum does not meet either the Huntington, or the Perlmutter and LeoGrande benchmark points used to determine the level of party oversight on the military. As such, the communist party hypothesis fits the comparative model underlined in this study, as being a possible reason for the continued rise of the Cuban MBC, and for why the Chinese and Vietnamese MBC regimes have not expanded.

It is important to note, however, that this does not suggest that the Cuban Communist Party is an illegitimate actor in itself. Membership in 2003 totaled approximately 856,000 active participants, making it the largest institution in Cuban society (Mujal-León and Buzón 2008, 409). The PCC is a leading and influential governing institution in Cuba, but it lacks the strong components needed to oversee and counterbalance the FAR's operation and wide political clout. 


\section{$\underline{B A}$ Model - Military Institutional Rule Analysis}

The BA model was initially presented to challenge modernization theories of democratization and industrial development. According to classical modernization theory, capitalist industrialization and economic development tend to occur in societies that have a steady wave of democratization (O’Donnell 1979). The BA model challenges this notion by explaining the rise of authoritarian regimes in South America that attempted to form capitalist private enterprises and increased industrialization by repressing popular democratic institutions and groups (O’Donnell 1979). This model challenged many older theories that considered democracy a prime requirement for capitalism. In the Cuban context, it can help explain why the FAR's existence in the economy has continued to expand.

Collier stipulated from his collection of works on BA regimes, that one of the prime BA characteristics is that military rule is carried out on an institutional basis, which consists of a military establishment that does not depend on the authority of one individual. Authority and decision-making are then spread out and decentralized across a wide range of actors of military personnel (Collier 1979).

The Chinese MBC began under the leadership of Deng Xiaoping, a legitimate general in the PLA, and rival to Mao Tze-tung. Deng was the official chair of the CMC from 1978-1989, then indirectly until his death in 1994. He took active decision making in the CMC institution, and relied on the presence of loyalist such as Hanz Shangkun. The role played by Hanz was to ensure Deng's central authority within the CMC institution (Mulvenon 2001). In the Vietnamese case, military President Lu Duc Anh, and his appointment of Secretary Le Kha Phieu, ensured a limited bureaucratic presence of 
military interest. Le was known to have his own sphere of authority during his time as party secretary, until he was removed and replaced in 1997 (Vasavakul 2001). Yet, these examples of Vietnamese and Chinese military delegation of authority are limited. They pale in comparison with the wave of military generals who have been appointed by President Raúl Castro in the Cuban example. The Vietnamese and Chinese examples of delegated authority do not match the conditions underlined by O'Donnell and Collier regarding the BA model, which stipulate various military officers with independent authority (Collier 1979).

The implications presented by the BA variable do not downplay the authority of President Raúl Castro as a crucial leader in the Cuban leadership, but it is well known that Raúl Castro’s authority is based more on military support from various generals and FAR officers than on civilian party officials (Maingot 2007). The fact that FAR officers hold much sway in various government ministries and economic corporations suggests that the Cuban military is a leading institution that exists outside of the jurisdiction of the local communist party. Thus, the BA hypothesis is a prime reason for as to why the Cuban MBC is able to expand in contrast to the Chinese's and Vietnamese's contractions.

\section{Conclusion of Study}

The overall conclusion of this study is that the Cuban MBC has increased because the FAR is gradually becoming the most prominent institution to manage the Cuban economy and government. The Chinese and Vietnamese MBC regimes have decreased, partly because of the corruption cases, as with the Chinese example, but mostly because both the PLA and the VPA have to contend and coexist with an equally strong and 
influential party apparatus that limits the independent economic spheres of military interest. The FAR does not contend so much with a party apparatus, but influences and uses the PCC as a political tool; a fact that sets it apart from its Chinese and Vietnamese counterparts.

The fact that the Cuban Communist Party possesses limited or no institutional control over the armed forces is an explicit explanation for the FAR's economic power and political influence. This argument is clearly expressed in a statement by a Latin American diplomat who was stationed in Havana in 1995.

[The] reality of Cuba in 1995 is that the military is one of the few, if not the only, institution that really and truly works. Revolutionary fervor has vanished, and with it the credibility of the party, leaving only the armed forces to fill the vacuum (Cited in Mora 2004, Technocrat, 7).

The argument of the third independent variable is also a fact to consider. The waves of generals who have been appointed to key ministerial and economic positions in the Cuban context helps explain Cuba's increasing military presence. Apart from the Chinese and Vietnamese MBC regimes, which involved military industries obtaining limited degrees of autonomy from their local communist party institutions, the Cuban MBC has involved many high-level FAR generals obtaining political positions, in addition to economic assignments. These include, for example, key sectors such as domestic security (Ministry of Interior), agriculture (Ministry of Agriculture) and tourism (Ministry of Tourism). These economic and political assignments represent similar occurrences seen in BA regimes in Argentina, Brazil and Chile in the 1960s and 1970s, which involved a circle of military generals implicated in government ministries, and isolating other civilian political figures (O’Donnell 1988). Cuban Minister of Defense, 
General Julio Casas Regueiro, summarized it well in the mid-1990s when he publicly stipulated that “Civilians better learn to behave as soldiers” (Cited in Mora 2004, Technocrat, 10).

It is important to understand that, in the Cuban context, both the communist party and BA hypotheses are interconnected. The fact that the Cuban communist party does not possess a reliable oversight mechanism over the FAR is a clear catalyst for the rise of FAR generals to key government and economic positions. In a sense, the rise of a bureaucratic FAR institution is a result of a power vacuum left by an underdevelopment of civilian institutions. This argument is comparatively corroborated by looking at the Chinese and Vietnamese MBC counterparts, which possess a heavy involvement of liaison institutions, such as the Chinese CMC and the Vietnamese CMPC, and prevent complete independence by PLA and VPA officers. The fact that the Ministry of Interior, the strongest Cuban institution capable of providing effective oversight over the Cuban MBC, was shifted to FAR jurisdiction in 1989 suggests that coordinated communist party authority within the military enterprises is non-existent.

The current study does not conclude that the Chinese and Vietnamese militaries are completely subservient to general local party authority. One must remember that there have been historical cases of military resistance and criticism of party leaders in both the Chinese and Vietnamese political contexts. Many scholars label this as "Conditional Compliance” within party-military relations (Mora 2002). Communist parties will respect military autonomous spheres of interest that the military is more equipped and capable to handle: i.e. national defense and domestic security. In return, the military will respect party, and ultimately civilian, fields of interests such as economic and social 
development. This form of party-military relation is evident in the Chinese and Vietnamese examples, which consist of the communist party and the military simultaneously competing and coexisting with one another (Mora 2004, Business). Such a form of relations is not evident in the Cuban example, as the communist party is more of a supportive tool used by the military.

These are the scenarios that have emerged in the three case studies, and may explain the factors that cause military-economic involvements to expand and contract. When there is a rival civilian institution that can offer civilian oversight over the military, then military-economic involvement will probably decrease or be prevented from expanding. However, if there is a gap in civilian control over the military, coupled with a legitimate bureaucratic military entity, then military-economic involvement can increase and expand into various areas of the economic sector

These conclusions are useful when applied to other countries such as Indonesia, Iran, Pakistan and Turkey. These countries all have strong cases of military-economic involvement, which are different from the cases seen in MBC regimes, in the form that they do not have the fundamental elements of military-party relations, but are similar in the current day roles the military plays in managing economic affairs. It is possible then to examine and validate whether the two hypotheses underlined in this study of 1) weak civilian military oversight, and 2) bureaucratic military existence, play a role in affecting the military economic involvement in other countries. Such can help present a clear picture and understanding of the domestic and foreign policy decisions enacted by regimes that possess a highly influential economic-military institution. 


\section{BIBLIOGRAPHY}

Amuchastegui, Domingo. “FAR: Mastering Reform.” In Cuba in Transition, Volume 10. ASCE, 2000.

Amuchastegui, Domingo. “Cuba’s Armed Forces: Power and Reform.” In Cuba in Transition, Volume 9. ASCE, 1999.

Báez, Luís. Secretos de generales. Barcelona, España: Losada, 1997.

Banks, Arthur S. Thomas C. Muller. William R. Overstreet. Political Handbook of the World 2008. Washington D.C.: CQ Press, 2008.

Cheung, Tai Ming. China's Entrepreneurial Army. New York: Oxford University Press, 2001.

Collier, David. “The Bureaucratic-Authoritarian Model: Synthesis and Priorities for Future Research.” In David Collier Ed., The New Authoritarianism in Latin America, pp., 363 -97. Princeton, New Jersey: Princeton University Press, 1979.

Díaz-Briquets, Sergio, and Jorge Pérez-López. Corruption in Cuba: Castro and Beyond. Austin; Texas University Press, 2006.

Espinosa, Juan Carlos. "Vanguard of the State: The Cuban Armed Forces in Transition." In Irving Louis Horowitz and Jaime Suchlicki Eds., Cuban Communism: 1959-2003, pp., 366-87. New Brunswick and London: Transaction Publishers, 2003.

Goncharov, Sergei N., John W. Lewis and Xue Litai. Uncertain Partners: Stalin, Mao and the Korean War. Stanford; Stanford University Press, 1993.

Gonzáles, Edward. Cuba Under Castro: The Limits of Charisma. Los Angeles: Houghton Mifflin Company, 1974.

Hmong National Development. "Hmong National Development Appeals for End to Illegal Logging, Military Attacks in Laos.” http://www.illegal-logging.info/item_single.php?it_id=2846\&it=news. Hmong National Development, Inc. 2008

Huntington, Samuel P. The Soldier and the State: The Theory and Politics of CivilMilitary Relations. Cambridge: Harvard University Press, 1957.

Ji, You. “Sorting out the Myths about Political Commissars.” In Nan Li Ed., Chinese Civil-Military Relations: The Transformation of the People's Liberation Army, pp., 89-116. London and New York: Routledge, 2006. 
Joffe, Ellis. "The Chinese army in domestic politics: factors and phases."

In Nan Li Ed., Chinese Civil-Military Relations: The Transformation of the People's Liberation Army, pp., 89-116. London and New York: Routledge, 2006.

Klepak, Hal. Cuba’s Military 1990-2005: Revolutionary Soldiers During CounterRevolutionary Times. New York: Palgrave, 2005.

Latell, Brian. After Fidel: Raul Castro and the Future of Cuba's Revolution. New York: Palgrave, 2005.

LeoGrande, William M. "A Bureaucratic Approach to Civil-Military Relations in Communist Political Systems: The Case of Cuba.” In Dale R. Herspring and Ivan Volgyes Eds., Civil-Military Relations in Communist Systems, pp., 201 -18. Boulder: Westview Press, 1978.

Liphart, Arend. "Comparative Politics and the Comparative Method.” The American Political Science Review 65 (3): 682-93. 1971.

Ma, Shun-Yu. "The Rise and Fall of Bureaucratic-Authoritarianism in Chile.” In Studies in Comparative International Development, 34(3): 51-65. 1999.

Maingot, Anthony P. "The Inevitable Transition: From Charismatic to MilitaryBureaucratic Authority in Cuba.” Cuban Research Institute. Report No. 3. 2007.

Mora, Frank O. "The FAR and Its Economic Role: From Civic to Technocrat-Soldier.” Institute for Cuban \& Cuban-American Studies Occasional Paper Series. 2004.

Mora, Frank O. "Military Business: Explaining Support for Policy Change in China, Cuba and Vietnam.” Problems of Post-Communism 51 (6): 44-63. 2004.

Mujal- León, Eusebio and Lorena Buzón. "Exceptionalism and Beyond: Civil-Military Relations in Cuba, 1986-2008” In Cuba in Transition, Volume 18. 2008.

Mulvenon, James. Soldiers of Fortune: The Rise and Fall of the Chinese MilitaryBusiness Complex, 1978-1998. New York: M. E. Sharpe, 2001.

O’Donnell, Guillermo A. Bureaucratic-Authoritarianism: Argentina, 1966-1973, in Comparative Perspective. Translated by James McGuire in collaboration with Rae Flory. Berkeley: University of California Press, 1988.

O’Donnell, Guillermo A. Modernization and Bureaucratic-Authoritarianism. Berkeley: University of California Press, 1979. 
Pérez, Omar Everleny Villanueva. “The Cuban Economy Today and Its Future Challenges.’ in Jorge I. Domínguez, Omar Everleny Pérez Villanueva and Lorena Barberia Eds., The Cuban Economy at the Start of the Twenty-First Century, pp., 4990. Cambridge: Harvard University Press, 2004.

Perlmutter, Amos and William M. LeoGrande. "The Party in Uniform: Toward a Theory of Civil-Military Relations in Communist Political Systems.” In The American Political Science Review 76 (4): 778-89. 1982.

Rodríguez, Juan Antonio. Cuba Por Dentro: El MININT. Miami: Ediciones Universal, 1996.

Shirk, Susan L. 2007. China: Fragile Superpower. New York: Oxford University Press, 2007.

Stern, Lewis. The Vietnamese Communist Party's Agenda for Reform: A Study of the Eight National Party Congress. London: McFarland \& Company, Inc, Publishers, 1998.

Sweig, Julia E. Cuba: What Everyone Needs to Know. New York: Oxford University Press, 2009.

Thayer, Carlyle. “The Economic and Commercial Roles of the Vietnam People's Army. " In The Military as an Economic Actor, edited by Jorn Brommelhorster and Wolf-Christian Paes, 74-93. New York: Palgrave, 2003.

Thayer, Carlyle A. The Vietnam People's Army Under Doi Moi. Singapore: Institute of Southeast Asian Studies, 1994.

Vasavakul, Thaveeporn. "Vietnam: From Revolutionary Heroes to Red Entrepreneurs.” In Muthiah Alagappa Ed., Coercion and Governance: The Declining Political Role of ,pp.,336-56. Stanford: Stanford University Press, 2001.

Waters, Mary-Alice, ed. 1999. Making History: Interviews with four generals of Cuba's Revolutionary Armed Forces. New York: Pathfinder Press, 1999. 